\title{
Trump v. Biden: An Opinion for a Hypothetical Case
}

\author{
EDWARD B. FOLEY*
}

The discussion convened by OSU's Election Law program on May 4 focused, in its first session, on the possibility of litigation in the November presidential election arising from the failure of many Philadelphia voters to receive absentee ballots that they had properly and timely requested under Pennsylvania law. This hypothetical scenario was modeled in large part on the real-world electoral crisis that had occurred in Wisconsin during its April primary, when as many as 14,000 voters failed to receive an absentee ballot before Election Day, even though these voters had complied with the state's statutory deadline for requesting an absentee ballot. Local election officials had become overwhelmed with the large volume of these requests and could not handle administratively their responsibility to deliver a ballot to voters so that there would be time for voters to cast these ballots in the election.

As a result, Wisconsin voters sued in federal district court seeking a remedy that would permit them additional time to return their absentee ballots so that they would count. The district court granted emergency relief, specifying that voters would have six additional days after Election Day, April 7, in which to cast and return their absentee ballots. In $\underline{R N C} v$. DNC, however, a majority of the U.S. Supreme Court objected to a portion of the district court's decree. While the Supreme Court accepted the district court's ruling insofar as it required absentee ballots cast and postmarked on or before Election Day to be counted if local election officials received them within the next six days, the Supreme Court negated the district court's order insofar as it required the counting of ballots cast after Election Day had passed. The majority explained: "Extending the date by which ballots may be cast by voters - not just received by the municipal clerks but cast by voters - for an additional six days after the scheduled election day fundamentally alters the nature of the election."

The Philadelphia-based hypothetical scenario discussed in the May 4 event was designed to consider whether the outcome of litigation would be different if the district court had fashioned a different form of remedy to protect voters from the disenfranchisement caused by failure to receive a timely requested absentee ballot. One alternative form of remedy would be to permit absentee voters who do not receive their absentee ballots, as they should have, to download a substitute ballot and, after printing it out, cast and postmark it on or before Election Day. This kind of substitute absentee ballot is already available for military and overseas voters. Known as the Federal Write-In Absentee Ballot (FWAB), it is required by Congress to protect military and overseas voters from just the kind of disenfranchisement that thousands of Wisconsin voters suffered. What if the district court had ordered that a FWAB-like substitute be available to any voter who had properly requested an absentee ballot under state law but 
who had not yet received it by Election Day? Or, looking ahead to November, what if the same type of problem arises, and a court is asked to protect voters from this type of disenfranchisement.

The discussion of this topic on May 4 was illuminating but not definitive. Many participants said that they would need to see the specific circumstances of litigation over a judicially crafted FWAB-like remedy in order to assess its validity. Consequently, the following is an attempt to spell out the facts of a hypothetical scenario and put them in the form of a hypothetical U.S. Supreme Court opinion, so that readers can appraise for themselves whether they would agree or disagree with a ruling that distinguishes $R N C v$. DNC and upholds the validity of a FWAB-like remedy against a federal constitutional challenge.

Since May 4, this year's problems in the administration of elections have also included the massive failures in Georgia on June 9, where voters in multiple polling locations were waiting in line for up to seven hours. Accordingly, the idea arises whether a FWAB-like remedy might also be suitable for voters disenfranchised by this long-line situation. What if a court, in response to an emergency motion on Election Day, ordered that voters who had been waiting in line for over one hour but who were unable to wait in line any longer would be entitled to cast a FWAB-like ballot instead as long as it was postmarked on Election Day? Would that be a constitutionally acceptable remedy and, given the ruling in $R N C v$. $D N C$, more advisable than a judicial decree that permitted voters to cast a ballot on some day subsequent to Election Day itself?

The following hypothetical opinion incorporates this long-line problem into the facts of the case. It is thus designed to test one's views about the use of a FWAB-like remedy to redress two forms of disenfranchisement: (1) the failure of receive a timely requested absentee ballot; and (2) the inability to vote at the polls despite waiting in line for over an hour. (It would be possible to choose two hours, rather than one, as the point at which this FWAB-like remedy would become available, with voters having to attest to the length of their wait in line; but if it were constitutionally permissible for a state court to order this remedy for voters suffering a two-hour wait, would the remedy no longer be constitutional for only a one-hour wait? The main issue would seem to be where a state court could go down this remedial road at all. It is a significant distinction between $R N C$ v. DNC and this hypothetical case that the latter involves U.S. Supreme Court review of a state supreme court decision, rather than review of a lower federal court's order.) If contrary to the reasoning and conclusion of this hypothetical opinion this type of remedy is not constitutionally permissible for either form of disenfranchisement, then is the inevitable conclusion that such disenfranchisement must be considered constitutionally acceptable in the event that either type of administrative breakdown of the voting process occurs? 


\title{
THE SUPREME COURT OF THE UNITED STATES
}

\author{
DONALD TRUMP ET AL., PETITIONERS \\ $\mathrm{V}$. \\ JOSEPH BIDEN, ET AL. \\ ON WRIT OF CERTIORARI TO THE SUPREME COURT OF \\ PENNSYLVANIA
}

[November 6, 2020]

\section{PER CURIAM.}

This year's elections, including the popular vote that state legislatures have authorized for purposes of appointing presidential electors, has been conducted under extraordinarily difficult conditions as a consequence of the coronavirus pandemic. The challenges of conducting these elections in the conventional mode of voting in person at a neighborhood polling location on Election Day, where there is a risk of spreading the deadly virus even with sound protocols for social distancing and other hygienic practices in place, has caused an unprecedented spike in applications to vote by mail, where that option is available to voters by state law. It has also caused a shortage of poll workers to administer the voting process at polling locations on Election Day.

Pennsylvania is one of many states that has struggled to handle these challenges successfully. As Election Day approached it became increasingly apparent that thousands of the state's voters, especially in Philadelphia, would not receive the vote-by-mail ballot that they had properly requested pursuant to newly enacted provisions of Pennsylvania law. Moreover, on Election Day itself, many voters - in Philadelphia and elsewhere - faced waiting times of several hours. The Pennsylvania Supreme Court has attempted to ameliorate these conditions, but its efforts are now challenged here as unconstitutional.

President Donald Trump, as a candidate for reelection and the lead petitioner here, specifically asks this Court to hold that the Pennsylvania Supreme Court has violated the U.S. Constitution by construing its own state constitution to require the counting of emergency vote-by-mail ballots made available to voters who properly had applied for a regular vote-by-mail ballot but who not yet had received it by Election Day, November 3. In a subsequent ruling, the Pennsylvania Supreme Court also ordered the counting of these emergency ballots if cast by any voter who, after waiting in line for more than one hour to vote in person at a polling place on November 3, signed an affidavit that the voter was unable wait in line any longer and therefore needed to cast an emergency vote-by-mail ballot in order to avoid disenfranchisement. President 
Trump and his co-petitioners also claim this additional ruling violates the federal Constitution.

We reject both federal constitutional claims and hold instead that Pennsylvania may count emergency ballots cast by eligible and registered voters so long as those ballots are cast on or before Election Day and are offered to voters in a truly emergency situation in furtherance of the obligation, imposed by both state and federal constitutional law, to provide an equal opportunity of all voters to cast a timely ballot in the same statewide election.

\section{I}

In advance of this year's election, Pennsylvania adopted a new system of no-excuse vote-by-mail, meaning that any eligible and registered voter who would prefer this method of casting a ballot, rather than going in person to a precinct polling place, would be entitled to choose this method without needing to justify this choice. According to the new statute enacted by the state's legislature, if a voter applies for a vote-by-mail ballot by the deadline (5 p.m. on the Tuesday before Election Day, 25 P.S. $\S 3150.12 a$ ), the county board of elections "shall deliver or mail" the ballot to the voter within "48 hours" of receiving the application. 25 P.S. $\S 3150.15$. The statute, in turn, obligates the voter to return the cast ballot by 8 p.m. on Election Day. 25 P.S. $\S 3150.16$. As the state's own official website emphasized to voters, "postmarks are not enough" and instead "VOTED BALLOTS must be RECEIVED by your county election office" within this statutory deadline.

As this year's general election on November 3 approached, however, it became increasingly clear that some local elections boards, including Philadelphia's, were unable to comply with their own obligation to send ballots to voters within the 48-hour turnaround time specified by the state statute. Because of the extraordinarily large volume of applications for these ballots, triggered by the coronavirus pandemic, local election officials simply could not keep pace with the applications and a backlog had developed. It became evident that many thousands of voters (over 10,000 and perhaps even 50,000, according to both official statistics and media reports), who had properly requested ballots by the statutory deadline of October 27 , would not even receive a ballot by Election Day, November 3, much less be able to return it by then, because local election officials still had been unable to process these timely applications - in violation of their own statutory obligation to do so within 48 hours.

Respondents here, including former Vice President Joe Biden and his presidential campaign, filed an emergency petition in the Pennsylvania Supreme Court, asking the court to provide a remedy that would avoid the disenfranchisement of qualified voters who had complied with state law in applying for a vote-by-mail ballot. The court granted the petition, ordering that any voter whose vote-by-mail application had been received by the statutory deadline of 5 p.m. on October 27, but whose application has not been processed within 48 hours later as required by state law (as demonstrated by the local 
election board's own records on its handling of absentee ballot applications), would be entitled to cast a substitute emergency vote-by-mail ballot that the state would be obligated to count as a valid ballot as long as it had been delivered or postmarked by 8 p.m. on Election Day, November 3. The court further explained that, as a model for the type of emergency vote-by-mail ballot that would be appropriate, the Federal Write-In Absentee Ballot (FWAB) available to military and oversea $\mathrm{s}$ voters could be extended to cover this additional emergency circumstance. In essence, the Pennsylvania Supreme Court decreed that voters in the covered situation - having timely applied for a regular voteby-mail ballot but whose application had been unlawfully delayed beyond the statutory 48-hour period-were entitled to utilize the downloadable FWAB in this emergency situation, although the state's chief elections officer (Secretary of State Kathy Boockvar, a respondent here) could provide a state-specific alternative to the FWAB as long as it was functionally equivalent in permitting a voter to cast a ballot and avoid disenfranchisement (and also as long as the state-specific alternative was uniform statewide, so that there was no danger of local variation in voting opportunities available to similarly situated voters in the same statewide election). The Pennsylvania Supreme Court based its decision on both the statutory violation committed by local election officials in missing their 48-hour turnaround obligation and in the state constitution's guarantee of a "free and equal" election.

The Pennsylvania Supreme Court rendered its decision on Friday, October 30. Petitioners, including President Donald Trump and his reelection campaign, immediately sought a stay in this Court. The next day, October 31, we issued an order providing that no emergency ballot cast pursuant to the state court's order would be entitled to be counted absent further order of this Court, but that the state and local election officials were not enjoined in receiving any emergency ballot cast pursuant to the Pennsylvania Supreme Court's decree, and that this Court would hear argument in the case on Wednesday, November 4, after briefing from both sides. On November 1, the Pennsylvania Department of State released a directive informing voters that they were entitled to use either the existing FWAB according to the terms set forth in the Pennsylvania Supreme Court's decision or a state-specific alternative that the Department of State had fashioned as permitted by the court's decision and made available on its own website.

Meanwhile, Election Day occurred on November 3. Early in the morning, excessively long lines began to develop at multiple polling locations in Philadelphia and elsewhere in the state. Evidence showed these lines were largely attributable to an insufficient number of poll workers, caused in part by "no shows"-individuals who had agreed serve as poll workers but who ultimately did not report for duty, likely because of increased fears concerning a new spike in Covid-19 cases during the week prior to Election Day. Pursuant to another emergency petition filed by the Biden campaign, the Pennsylvania Supreme Court at 3 p.m. released a second decree announcing that any voter who had been standing in line at a polling place for over one hour that day was 
entitled to use the FWAB, or the Department of State's equivalent emergency ballot, if in submitting their ballot they included a sworn notation that they were unable to wait in line any longer and instead were using this emergency ballot as the only means available to cast their votes. The state supreme court made clear that, as with its initial ruling on October 30, these emergency ballots would be eligible to be counted as long as they were postmarked or delivered to the appropriate county election board, including in designated drop boxes, by 8 p.m. that same day, November 3.

Later in the evening of Election Day, petitioners filed a supplemental brief in this Court arguing that the Pennsylvania Supreme Court's second order, like its first, violates the federal Constitution. Late that same night, we clarified that our previous order, preventing any ballots challenged by petitioners from being counted absent further order of this Court, extended to the Pennsylvania Supreme Court's second ruling as well as its first. Oral argument before this Court the next morning, November 4, encompassed consideration of both rulings by the state supreme court.

We now issue this decision.

Petitioners argue that it violates the federal Constitution for the Pennsylvania Supreme Court to alter Pennsylvania law governing the conduct of the current election, in a way that deviates from the explicit and unambiguous requirements set forth by the state's legislature in its statutory text, after ballots already have begun to be cast in the midst of this specific election. In making this federal constitutional argument, petitioners rest on two alternative theories. First, petitioners assert that deviating from the plain statutory text in the way that the Pennsylvania Supreme Court did violates the authority of the state's legislature, as vested by Article II of the federal Constitution, to determine the manner of appointing the state's presidential electors. Second, petitioners claim that to change state law in the middle of an election, as the Pennsylvania Supreme Court did, violates the due process clause of the Fourteenth Amendment.

We consider each of these alternative arguments in turn.

A

Article II of the U.S. Constitution provides: "Each state shall appoint, in such manner as the Legislature thereof may direct, a number of electors, equal to the whole number of Senators and Representatives to which the State may be entitled in the Congress." (Emphasis added ). In Bush v. Palm Beach Canvassing Board, this Court unanimously expressed concern that the Florida Supreme Court had deviated from the state's statutory rules for conducting a popular vote to appoint the state's presidential electors - and that this deviation was such as to violate the state legislature's Article II authority to choose the 
manner of appointing the electors. 531 U.S. 70 (2000) (per curiam). Finding ambiguity in the Florida Supreme Court's decision under review, however, we remanded the case for clarification rather than ruling definitively on the claim of a constitutional violation before us there.

In Bush v. Gore, Chief Justice Rehnquist's concurrence (joined by Justice Scalia and JUSTICE ThOMAS) would have found the Florida Supreme Court's subsequent decision involving the disputed 2000 presidential election a violation of Article II, reasoning that it was an excessive distortion of the applicable state statutes as enacted by the Florida legislature. 531 U.S. 98 (2000). The Court's per curiam majority opinion, however, did not rest on this Article II analysis, but instead held that the Florida Supreme Court had violated the equal protection clause of the Fourteenth Amendment by approving a statewide recount that permitted county-by-county variation (and even within single counties ballot-by-ballot variation) in the assessment of whether physically identical ballots were entitled to be counted. The four dissenting opinions in Bush v. Gore rejected the Article II claim in the case, believing the Florida Supreme Court's opinion to be a plausible interpretation of the state's applicable statute even if that interpretation was not correct or even the most reasonable one.

Here, we reject the claim that the Pennsylvania Supreme Court has violated Article II by usurping the state legislature's constitutional authority to determine the manner in which the state's presidential electors are appointed. While recognizing that there could indeed be circumstances in which a state court 's purported interpretation of a state statute would be so egregious as to be that type of usurpation in violation of Article II, this case is not one that presents such circumstances. Rather than distorting the statutory rules for conducting a statewide popular vote to appoint electors, the Pennsylvania Supreme Court was providing a remedy for the violation of those statutory rules caused by the failure of local election boards to deliver vote-by-mail ballots within the 48-hour period statutorily specified to voters who properly requested them.

To be sure, the Pennsylvania Supreme Court's remedy permits vote-bymail ballots to be counted as long as they are postmarked by 8 p.m. on Election Day, rather than being received at the local board of elections by that time. Petitioners contend that this remedy is an impermissible rewriting of the legislature's statutory language, which explicitly and unambiguously provides (except for military and overseas voters, who are covered by separate rules): "a completed mail-in ballot must be received in the office of the county board of elections no later than eight o'clock P.M. on the day of the primary or election." 25 P.S. $\S 3150.16$. Petitioners argue that to rewrite the statutory deadline for the submission of vote-by-mail ballots in this way must amount to a contravention of the state legislature's Article II authority to determine the method for appointing the state's presidential electors.

We disagree. We view the statutory obligation of voters to return their completed ballots by 8 p.m. on Election Day as part of the overall statutory rules that the legislature adopted for vote-by-mail. These rules also included the 
statutory obligation of local election officials to deliver ballots to voters within 48 hours after receiving a voter's timely request, so that the voters would be able to comply with their own statutory deadline for returning their ballots. Once the prerequisite part of the statutory scheme had been violated by the local government officials themselves, it was no longer possible to enforce the deadline set for voters in order to effectuate the plan of the overall statutory structure.

It is evident that the Pennsylvania legislature's objective was to have the state's presidential electors chosen by a popular vote in which all of the state 's eligible voters had an opportunity to participate. Furthermore, by adopting its new vote-by-mail procedures, the legislature wanted to provide vote-by-mail as a method of voting that all eligible voters, at their own discretion, were entitled to choose as their preferred means of casting a ballot. The Pennsylvania Supreme Court's remedy for the local government's failure to deliver vote-bymail ballots before Election Day to voters who had properly requested them, rather than distorting the will of the legislature concerning the manner of appointing the state's presidential electors, was as preservative of the legislature's will as possible in light of the local government's own statutory violation. While in other contexts it is possible that a state judicial decree might contravene the legislature's choice on the manner of appointing electors, in this case the Pennsylvania Supreme Court's decree was consonant with the legislature's choice and thus not a violation of Article II.

Petitioners also argue that the use of emergency "absentee" ballots as a form of voting for voters waiting in line at their polling place on November 3 for over one hour is not an electoral procedure provided for by Pennsylvania's statutory law and therefore the Pennsylvania Supreme Court 's adoption of this procedure in response to a perceived problem of excessively long lines at the polls was another type of rewriting of the state's applicable statutory law in usurpation of the legislature's Article II authority. We acknowledge that the Pennsylvania Supreme Court's remedy was unorthodox, and we share the concern that without adequate security measures permitting voters to cast a lastminute absentee ballot when they had not requested one previously, just because they encounter some problem or inconvenience when they go to the polls on Election Day, has the potential for mischief that conceivably could undermine the integrity of the election. We expect that, before counting any ballot cast in this unorthodox manner, election officials would engage in extra scrutiny to verify its authenticity, and it would be essential to permit any candidate to challenge a specific ballot as uncountable because it could not be adequately verified as cast by an eligible voter who otherwise would have been disenfranchised because of excessively long lines at the polls on Election Day.

Even so, we do not believe that the mere fact that the Pennsylvania Supreme Court authorized this unorthodox procedure, without more, necessarily violates the legislature's Article II authority to choose the manner of appointing presidential electors. As just stated, the main feature of the method that Pennsylvania's legislature has chosen is that the appointment of its electors shall 
be made by a popular vote of the statewide constituency. Excessively long lines at the polls on Election Day, which cause voters to abandon their place in line without having cast a ballot because after waiting for hours already they can wait no longer, contravenes the legislature's chosen method for appointing the state's electors. The popular vote is not a fair or accurate reflection of the statewide constituency's will if part of that constituency, as a practical matter, is unable to cast a ballot because of grossly unreasonable waiting times at local polling places.

We have found nothing in Pennsylvania's statutory law that explicitly precludes the use of emergency absentee ballots as a means of remediating an acute problem of excessive wait times developing at polling places on Election Day. We do find in Pennsylvania's statutes specific measures aimed at avoiding lengthy lines at the polls, including a longstanding rule that no voter is permitted to spend "more than three minutes" casting a ballot by use of a voting machine in limited supply at the polling place unless other voters "are not waiting to vote" at the time. 25 P.S. $\S 3057$. (Pennsylvania statutory law also already permits military and overseas voters to return their absentee ballots up to a week after Election Day, and therefore to permit additional emergency absentee ballots to arrive within this same statutory deadline would not unduly impair the administration of this election ).

Moreover, given news reports that by midday in Philadelphia on November 3 , the waiting time to vote in many polling places had already exceeded three hours, the state was facing a crisis that warranted some form of emergency response. One advantage of the response the Pennsylvania Supreme Court adopted, while recognizing its countervailing disadvantages, was that it avoided the need to consider the possibility of opening the polls for an extra day of voting, either in Philadelphia or statewide. In light of all the logistical and other complexities that would have been associated with that different form of remediation, as well as our specific admonition recently against judicial alteration of an election that would permit the casting of ballots on days subsequent to Election Day itself, see $R N C v D N C$, we cannot say that it was unreasonable for the Pennsylvania Supreme Court to choose the remedy that it did. 589 U.S. _ (2020). Allowing a voter who can no longer wait in line to cast an emergency absentee ballot, especially when these emergency ballots already have been made available to voters who did not receive the official voteby-mail ballot that they properly requested, has the virtue of disrupting the election as minimally as possible. It also confines the election to ballots cast on or before Election Day, thus respecting an essential feature of the election as originally intended by the legislature.

Based on all these considerations, we concluded that the Pennsylvania Supreme Court did not violate Article II. 
Petitioners rely primarily on two appellate court precedents for the proposition that the Pennsylvania Supreme Court violated due process by changing the rules concerning the counting of vote-by-mail ballots after the casting of ballots had commenced in this election. In Griffin v. Burns, the court held that it violated due process for a state supreme court to invalidate absentee ballots cast by voters after the secretary of the state, as the chief elections officer in the state, had instructed voters that absentee ballots were a permissible method of voting in the election. , 570 F.2d 1065 ( $1{ }^{\text {st }}$ Cir. 1978). The "gotcha" aspect of voiding ballots cast by voters after they had already cast them in reliance on the rules as provided by the government itself was the core of the appellate court's due process holding.

In Roe v. Alabama, the court held that it violated due process to count absentee ballots that did not comply with the state 's statutory requirement that such ballots be notarized or have two witnesses. 68 F.3d 404 (11th Cir. 1995). After a trial that confirmed the state's previous practice of conducting elections to be almost uniformly consistent with this statutory requirement, the court ruled that it would violate fundamental fairness to abandon this statutory rule in the middle of the election, after ballots had been cast but before they had been counted. To do that, the court reasoned, would be equivalent to stuffing the ballot box after the polls closed with invalid ballots. Moreover, it would be unfair to eligible voters who, relying on the rules as they existed when the particular election began, decided against attempting to cast an absentee ballot because the notarization-or-two-witness obligation was more onerous than the would-be voters wished to undertake.

We do not dispute the soundness of these precedents. Even assuming that due process precludes changing the rules for counting ballots after they were cast in the ways that the state governments did in either of these two precedents, this case is different. . No voter here relied upon the statutory deadline of delivering vote-by-mail ballots to local election officials by 8 p.m. rather than postmarking them by that same deadline. No voter has been denied fundamental fairness by the Pennsylvania Supreme Court's efforts to remedy the disenfranchisement of eligible voters that would be caused by the failure of local election officials to administer elections properly according to the statutes in existence.

Not every deviation from electoral procedures set forth in state statutes violates due process, even if those deviations occur after the process for casting ballots in the particular election has begun. To be sure, such deviations inevitably raise suspicions and should be generally frowned upon. Sometimes, moreover, such deviations will be unconstitutional as an improper attempt to subvert an election. See Taylor v. Beckham 178 U.S. 548, 605-608 (1990) (Harlan, J., dissenting).

But due process analysis is context-dependent. Here, as we have already explained, the state government itself already was in violation of its own 
statutory rules for conducting this election. These violations led to demands for some form of remediation, under state law if not federal law, and the state supreme court chose a method of remediation calculated to be most congruent with the overall structure and objectives of the state's election laws. See generally Michael T. Morley, Election Emergencies, 67 Emory L. J. 545 (2018); for a Pennsylvania precedent on this point, see In re General Election-1985, 531 A.2d 836 (Pa. 1987).

Moreover, it is necessary for elections to comply with equal protection as well as due process. In numerous cases, starting with Reynolds $v$. Sims, this Court has held that the administration of elections must comply with the basic proposition that each eligible voter in a state has an equal right to participate in an election on essentially equal terms with each other eligible voter. 377 U.S. 533 (1964). For sake of simplicity, we and others have called this principle "one person, one vote." Cf. Bush v. Gore, supra, at 105 (applying this equal protection principle in a recount context). Although there are inevitable complexities in the implementation of this constitutional principle in particular circumstances, we have never abandoned the core proposition that this principle is an enforceable constitutional command.

In this election, there was considerable danger that without some form of emergency remediation the state would be in violation of the "equal opportunity to vote" constitutional principle. At the time that the Pennsylvania Supreme Court rendered its October 30 decision, some voters in the same statewide election had received their vote-by-mail ballots without delay, whereas other voters in the same election - and who had submitted their ballot applications on the same date as the first group of voters - had not. This difference in treatment of equivalent voters, with the consequence that one group would be able to cast a ballot in the election while the other group would not, understandably raised equal protection concerns. Likewise, on Election Day itself, in some polling locations in the same election voters were unable to receive a ballot to cast even after waiting more than three hours, while other voters in the same election were able to cast a ballot with a minimal wait or no wait at all. While we do not need to decide definitively that this differential treatment of equally eligible voters in the same election violates the federal constitutional requirement of equal protection (and the well-settled doctrine that federal courts should refrain from unnecessary constitutional pronouncements counsels against doing so), it suffices to acknowledge that the state's interest in avoiding this constitutionally problematic differential treatment of equivalent voters is adequate grounds for adjusting procedures in the pending election - especially when the difference in treatment is a consequence of the state's failure to follow its own statutory requirements. Just as there is some "play in the joints" between the Free Exercise Clause and the Establishment Clause of the First Amendment, so too must there be room for state and local election officials to maneuver between potential violations of equal protection, on the one hand, and due process, on the other. Cf. Locke v. Davey, 540 U.S. 712 (2004). A justifiable concern that the state would violate equal protection if it failed to remedy an electoral inequality of its 
own making, as here, can immunize the state from liability under the Due Process Clause for making a modest and suitably tailored adjustment in the enforcement of its existing election statutes in this limited respect.

In neither Griffin v. Burns nor Roe v. Alabama was a change in state law necessary to address an equal protection concern. In Griffin, there was no risk that counting absentee ballots cast by voters who had relied on the secretary of state'ss directives would harm any other voter in the same election. Similarly, in Roe there was no claim that disqualification of absentee ballots that failed to comply with the statutory rules for casting them-rules that had been uniformly applied in previous elections - would violate the equal protection rights of equivalent voters. Thus, Griffin and Roe are readily distinguishable, because here without the remedy provided by the Pennsylvania Supreme Court there would be a strong argument that the state was denying equal protection to equivalent voters by failing to provide them equal opportunities to cast a ballot in the same statewide election.

III

For the foregoing reasons, the partial stay of the Pennsylvania Supreme Court'ss rulings under review are hereby now lifted, and this matter is remanded to that court for further proceedings consistent with the foregoing.

It is so ordered.

* Charles W. Ebersold and Florence Whitcomb Ebersold Chair in Constitutional Law; Director, Election Law @ Moritz, The Ohio State University Moritz College of Law. 